\title{
Morphological characteristics of starch granules of Eastern and Central European potato varieties (Solanum Tuberosum)
}

\author{
Anastasia Zabolotets ${ }^{1}$, Vladimir Litvyak ${ }^{1}$, \\ Aliaksei Yermakou' ${ }^{2}$, Gulnazym Ospankulova ${ }^{3}$ \\ 1 - Scientific and Practical Center of the National Academy of Sciences of Belarus on Food, Minsk, \\ Republic of Belarus \\ 2 - Belarusian National Technical University, Minsk, Republic of Belarus \\ 3 - S. Seifullin Kazakh AgroTechnical University, Nur-Sultan, Republic of Kazakhstan
}

Keywords:

Starch

Native

Morphology

Grain

Potato

\section{Article history:}

Received

12.08.2018

Received in revised form

12.11.2018

Accepted

28.03.2019

\section{Corresponding} author:

Vladimir Litvyak

E-mail:

besserk1974@

mail.ru

\section{DOI:}

10.24263/2304-

974X-2019-8-1-4

\section{Abstract}

Introduction. Studies have been conducted to determine the effect of the size of starch granules on the quality of starch obtained from Eastern and Central European potato varieties.

Materials and methods. The object of study is native potato starch, produced according on technical regulatory legal acts from 15 potato varieties Belarusian, of Russian, of Ukrainian and of German selection. The morphological structure of starch granules was evaluated on a LEO 1420 scanning electron microscope. The contrast of the images was achieved by the metallization of preparations made with gold in the EMITECH K 550X vacuum system.

Results and its discussion. Grains of native starch obtained from Eastern and Central European potato varieties vary significantly in both shape and size, which, to a large extent, apparently, determine the technological features of starch production. It is noticed that, depending on the selection of Belarusian, German, Russian, Ukrainian, the size of the grains of native potato starch of Eastern and Central European varieties of potatoes varies within: $5-90,26 ; 8,38-83,47 ; 5,3-88,7 ; 12,36-$ 70 microns, respectively.

The highest starch content in grains obtained from Eastern and Central European potato varieties was found in the German selection variety «Kormoran» $-23 \%$. Among the varieties under consideration, it is he who has the highest starchiness, but at the same time small starch granules (the average size of the granules is 24,0 microns). Lowest starch content in grains derived from Eastern and Central European potato varieties was the lowest in the Russian «Krepysh» variety, 11,1\%, with an average granule size of 30,1 microns. On this basis, it can be assumed that with a larger average size of starch grains the starch content decreases, and with a smaller average size, the percentage of starch content increases.

According to our results, as well as well-known data, starch grains have an oval, spherical or irregular shape, their diameter varies between $0,001-0,2 \mathrm{~mm}$. Starch grains are divided into simple and complex: simple grains are homogeneous formations; complex - a combination of smaller particles. The density of starch is on average $1,5 \mathrm{~kg} / \mathrm{m}^{3}$.

Based on the analysis of the characteristics of the structure of native starch, it can be assumed that the main structural characteristic of the structure of native starch, determining its properties, is starch grain (granule).

Conclusion. The morphological structure of native starch granules depends on the type of potato and can vary widely: from 5-7 microns to 80-90 microns, which affects the quality of the starch produced. 


\section{Introduction}

The range of products of starch-treacle production is quite large and amounts to several hundred items [1-32]. The main raw materials for the production of starch and starch products are potatoes [5], corn [18-19,22, 27], wheat [11,15-16], rye [2], barley [12, 20], oats [4], rice [19, 21], buckwheat [2, 5], tapioca [23, 24], lentils [26], banana [25] etc.

Potato starch is widely used in the food industry, in cooking, in the production of certain types of sausages, to stabilize confectionery creams, and to produce artificial sago. Starch obtained from potatoes is also used for technical purposes in the textile, paper, printing industry, as well as in everyday life [1].

The use of starch is largely determined by its properties associated with the morphological structure. The peculiarities of starch morphology depend on the biochemical mechanisms of starch accumulation and are primarily determined by the grade of the raw material and its quality.

The size of starch granules has a significant effect on the quality of starch. Small granules swell worse and, accordingly, gelatinize more slowly, in addition, they are worse stored and inferior in taste to large ones.

In this regard, the purpose of this work was a comparative study of the morphological structure of native potato starch of Eastern and Central European varietal origin.

\section{Materials and methods}

\section{Materials}

The object of study is native potato starch, produced according on technical regulatory legal acts (TNLA) [33] from 15 potato varieties (Solanum tuberosum L.) [34-37], of which ten («Atlant» («Атлант»), «Lazurit» («Лазурит»), «Lasunok» («Ласунок»), «Lileya» («Лилея»), «Mag» («Маг»), «Skarb» («Скарб»), «Suzor'ye» («Сузорье»), «Yavar» («Явар»), «Vesnyanka» («Веснянка»)) Belarusian, thirteen («Lazar'» («Лазарь»), «Divo» («Диво»), «Vestnik» («Bестник»), «Effect» (Эффект), «Bryanskiy delikatesc» («Брянский деликатес»), «Favorit» («Фаворит»), «Grand» («Гранд»), «Vasilek» («Василек»), «Velikan» («Великан»), «Nakra» («Накра»), «Kolobok» («Колобок»), «Krepysh» («Kрепьиш»), «Meteor» («Memeop»)) of Russian, two («Dzvin» («Дзвин»), «Leleka» («Лелека»)) of Ukrainian and four («Albatros», «Kormoran», «Kranich», «Sonata») of German selection.

\section{Methods}

\section{Scanning Electron Microscopy (SEM)}

Sample preparation. Metallization of native starch preparations was carried out with gold in the EMITECH K 550X vacuum unit.

Analysis. Scanning electron micrographs of native starch granules were obtained using a LEO 1420 scanning (raster) electron microscope (Germany) [38-41].

The principle of operation of the scanning electron microscope consists in scanning the sample surface with a focused electron beam and analyzing particles reflected from it and Xray radiation resulting from the interaction of electrons with matter. In a scanning electron microscope, an electron beam (electron probe) is focused by electromagnetic lenses of a capacitor and a lens [6]. A special device - deflector deflects the electron beam (primary 
electrons), which slides on the surface (raster). The secondary electrons (reflected from the surface) are perceived by the detector and are focused on the screen of the scanning electron microscope creating a three-dimensional image. The scanning electron microscope allows working in a wide range of magnifications from $\times 10$ (which is equivalent to an increase in a strong hand-held lens) to $\times 1000000$, which is $\approx 500$ times the increase limit of the best optical microscopes. The scanning surface is necessarily sprayed with metal: platinum, gold, silver, aluminum [6].

\section{Determination of starch content in potato tubers}

The starchiness of potatoes is determined on the scales of the Steam [42].

Scales (Figure 1) consist of a long rocker, on which there are two parallel rulers with movable weights: a small one on the front ruler and a large one with a inside-in mobile ruler on the rear ruler. The back ruler is graded in divisions expressing the percentage of litter content (from 0 to $60 \%$ ). It is used to determine the contamination of potatoes and weigh the samples for analysis. The front line is graded on the percentage of starch in the range from 10 to $30 \%$ with an accuracy of up to $0,1 \%$ and is used for weighing in water by moving a small weight along the rocker arm [42].

The content of starch in the test sample of potatoes is determined by the position of the small weight on a certain division of the rocker arm on reaching equilibrium. The definition itself is made when a large weight is shifted all the way to the left, and a mobile ticker on it is pushed to the right. The ruler ends with directional arrows, above which there are two mobile small weights used to balance the tare of the scales, as follows. Two baskets (upper and lower) are suspended for a short rocker. In a tank in which the lower basket is placed, water is poured at a temperature of $17,5^{\circ} \mathrm{C}$. Both weights are pushed back and the mobile ruler is pushed to the left on the big weight until it stops. After this, the scales open and achieve the exact coincidence of the index arrows, first roughly: moving a large load on the short arm of the rocker arm, and then precisely: with small weights [42].

Due to the fact that the balance is calibrated at a temperature of $17,5^{\circ} \mathrm{C}$, it is necessary to measure the temperature of the water in the tank with each determination and to make a temperature correction (Table 1).

Table 1

Corrections for water temperature in determining starchiness on potato scales

\begin{tabular}{|c|c|c|c|c|c|c|c|c|c|c|c|c|c|c|}
\hline \multicolumn{15}{|c|}{ Water temperature when weighing, ${ }^{\circ} \mathrm{C}$} \\
\hline 7 & 8 & 9 & 10 & 11 & 12 & 13 & 14 & 15 & 16 & 17 & 18 & 19 & 20 & 21 \\
\hline & \multicolumn{7}{|c|}{ Add to scales } & & & & \multicolumn{4}{|c|}{$\begin{array}{l}\text { From indications of } \\
\text { scales to take away }\end{array}$} \\
\hline 0,2 & 0,2 & 0,2 & 0,2 & 0,2 & 0,1 & 0,1 & 0,1 & 0,0 & 0,0 & 0,0 & 0,0 & 0,0 & 0,1 & 0,1 \\
\hline 7 & 6 & 5 & 3 & 0 & 7 & 5 & 2 & 9 & 6 & 2 & 2 & 8 & 0 & 2 \\
\hline
\end{tabular}

\section{Statistical Analysis}

Statistical processing of the research results obtained using modern computer tools in accordance with generally accepted methods [3]. 


\section{Results and discussion}

\section{Results}

\section{Potato starch granules}

Scanning electron micrographs of grains of native starch obtained from Eastern and Central European potato varieties are shown in Figures 2 and 3. Figures 4, 5 and 6 show a grain size analysis of grains of native starch obtained from Eastern and Central European potato varieties (the distribution of starch granules according to their size).

The granulometric analysis of the grains of native starch was carried out on the basis of the results given in Table 2. Table 1 shows the average, minimum and maximum grain sizes of native starches obtained from Eastern and Central European potato varieties with the characteristics of the statistical processing of the studied sample.

Native starch grains obtained from Eastern and Central European potato varieties vary significantly in both shape and size, which, to a large extent, apparently, determine the technological features of starch production [4-6].

It was established that the average grain size of native starch obtained from Eastern and Central European potato varieties "Atlant», "Lazurit», "Lasunok», "Lileya», "Mag», «Skarb», «Suzor'ye», "Yavar», "Uladar», "Vesnyanka», "Albatros», "Kormoran», "Kranich», "Sonata», "Lazar'», "Divo», "Vestnik», "Effect», "Bryanskiy delikatesc», "Favorit», "Grand», «Vasilek», "Velikan», «Nakra», "Kolobok», «Krepysh», "Meteor», «Dzvin», «Leleka» respectively, will be: 28,23; 23,89; 21,61;26,03; 37,12; 25,54; 37,13; 26,$02 ; 26,29 ; 32,85 ; 33,72 ; 23,96 ; 33,90 ; 28,38 ; 27,68 ; 30,35 ; 34,13 ; 27,52 ; 21,32 ; 12,9 ; 33,1$; 32,$6 ; 31,4 ; 51 ; 31,9 ; 30,1 ; 27,9 ; 33,47 ; 33,27$ microns (tab. 1) [34]. At the same time, the minimum and maximum grain size of native starch obtained from Eastern and Central European potato varieties "Atlant», "Lazurit», "Lasunok», "Lileya», "Mag», "Skarb», «Suzor'ye», «Yavar», "Uladar», "Vesnyanka», «Albatros», «Kormoran», «Kranich», "Sonata», "Lazar'», «Divo», "Vestnik», "Effect», "Bryanskiy delikatesc», "Favorit», "Grand», "Vasilek», "Velikan», "Nakra», "Kolobok», "Krepysh», "Meteor», "Dzvin», «Leleka» fluctuates within: 7,84-56,22; 7,92-66,81; 5-56,25; 7,91-59,46; 12,92-65,42; $6,62-64,12 ; 14,58-67,64 ; 9,12-59,41 ; 6,43-58,39 ; 7,9-90,26 ; 8,46-62,64 ; 8,38-58,82$; $14,31-83,47 ; 10,97-62,64 ; 10,14-55,69 ; 15-56,58 ; 13,68-60,53 ; 9,47-58,94 ; 7-68,7 ; 5,3-$ 38,$4 ; 27,4-60,2 ; 11,4-88,7 ; 11,6-61,4 ; 15,1-80,8 ; 15,1-64,1 ; 10-61,1 ; 10,3-52,7 ; 12,36-70$; 15,14-60,28 microns (tab. 2) [34].

It should be noted that the maximum average grain size of native starch obtained from Eastern and Central European potato varieties was noted for «Nakra» variety and was 51 microns. The minimum average grain size of native potato starch was found in variety «Favorite» $-12,9$ microns. Both varieties of native potato starch belong to the varieties of Russian selection [34, 41]. 
Table 2

Morphological characteristics of native starch isolated from Eastern and Central European potato varieties

\begin{tabular}{|c|c|c|c|c|c|c|c|}
\hline \multirow{2}{*}{ Options } & \multicolumn{7}{|c|}{ Native starch extracted from Eastern and Central European } \\
potato varieties
\end{tabular}

Continuation of Table 2

\begin{tabular}{|c|c|c|c|c|c|c|c|}
\hline \multirow[b]{3}{*}{ Options } & \multicolumn{7}{|c|}{$\begin{array}{c}\text { Native starch extracted from Eastern and Central European } \\
\text { potato varieties }\end{array}$} \\
\hline & \multicolumn{3}{|c|}{$\begin{array}{c}\text { Varieties of Belarusian } \\
\text { breeding }\end{array}$} & \multicolumn{4}{|c|}{ German selection varieties } \\
\hline & 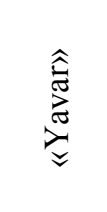 & 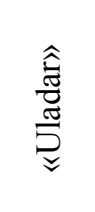 & 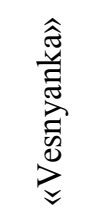 & 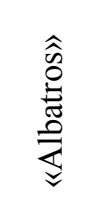 & 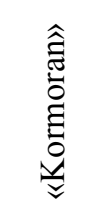 & 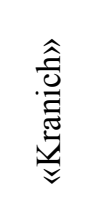 & 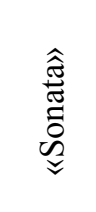 \\
\hline The average & 26,02 & 26,29 & 32,85 & 33,72 & 23,96 & 33,90 & 28,38 \\
\hline Minimum & 9,12 & 6,43 & 7,89 & 8,46 & 8,38 & 14,31 & 10,97 \\
\hline Maximum & 59,41 & 58,39 & 90,26 & 62,64 & 58,82 & 83,47 & 62,64 \\
\hline $\begin{array}{l}\text { Average starch } \\
\text { content, } \% \text {. }\end{array}$ & 11,4 & 14,7 & 18,3 & 17,2 & 23 & 16,7 & 16,9 \\
\hline $\begin{array}{l}\text { The distribution of } \\
\text { granules in size }\end{array}$ & \multicolumn{3}{|c|}{$\mathrm{A}$} & $\mathrm{B}$ & A & $\mathrm{B}$ & A \\
\hline
\end{tabular}


Continuation of Table 2

\begin{tabular}{|c|c|c|c|c|c|c|c|}
\hline \multirow[b]{3}{*}{ Options } & \multicolumn{7}{|c|}{$\begin{array}{l}\text { Native starch extracted from Eastern and Central European } \\
\text { potato varieties }\end{array}$} \\
\hline & \multicolumn{7}{|c|}{ Russian breeding varieties } \\
\hline & $\begin{array}{l}\hat{\hat{\tilde{\Xi}}} \\
\text { స్ } \\
\stackrel{\Xi}{\Xi}\end{array}$ & $\begin{array}{l}\hat{\hat{O}} \\
\stackrel{\partial}{\hat{\theta}}\end{array}$ & $\begin{array}{l}\hat{\hat{\hat{\theta}}} \\
\hat{\Xi} \\
\tilde{E} \\
\approx\end{array}$ & 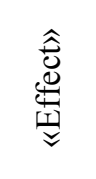 & 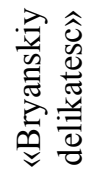 & 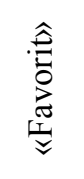 & 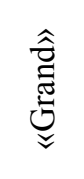 \\
\hline The average & 27,68 & 30,35 & 34,13 & 27,52 & 21,32 & 12,9 & 33,1 \\
\hline Minimum & 10,14 & 15,00 & 13,68 & 9,47 & 7 & 5,3 & 27,4 \\
\hline Maximum & 55,69 & 56,58 & 60,53 & 58,94 & 68,7 & 38,4 & 60,2 \\
\hline $\begin{array}{l}\text { Average starch } \\
\text { content, } \% \text {. }\end{array}$ & 20,4 & 21 & 18,5 & 19,5 & 16,6 & 14,5 & 15,7 \\
\hline $\begin{array}{l}\text { The distribution of } \\
\text { granules in size }\end{array}$ & A & $\mathrm{C}$ & A & $\mathrm{C}$ & $\mathrm{D}$ & $\mathrm{C}$ & $\mathrm{B}$ \\
\hline
\end{tabular}

Continuation of Table 2

\begin{tabular}{|c|c|c|c|c|c|c|c|}
\hline \multirow{2}{*}{ Options } & \multicolumn{7}{|c|}{ Native starch extracted from Eastern and Central European } \\
potato varieties
\end{tabular}

A - Monomodal, B - Bimodal, C - Threemodal, D - Fourmodal

It is noticed that, depending on the selection of Belarusian, German, Russian, Ukrainian, the size of the grains of native potato starch of Eastern and Central European potato varieties ranges from: 5-90,26; 8,38-83,47; 5,3-88,7; 12,36-70 microns, respectively [34]. 


\section{- Food Technology -}

The highest starch content in grains obtained from different varieties of potatoes was found in the German selection variety «Kormoran» - 23\%. This variety is of particular interest. Among the varieties under consideration, it is he who has the highest starchiness, but at the same time small starch granules (the average size of the granules is 24,0 microns) $[34,41]$.

The starch content in grains obtained from Eastern and Central European potato varieties was the lowest in the Russian «Krepysh» variety, 11,1\%, with an average granule size of 30,1 microns $[34,41]$.

On this basis, it can be assumed that with a larger average size of starch grains the starch content decreases, and with a smaller average size, the percentage of starch content increases.

As can be seen from Figures 1 and 2, fifteen varieties of native starches obtained from Eastern and Central European potato varieties («Atlant», «Lazurit», "Lasunok», «Lileya», "Skarb», "Suzor'ye», "Yavar», "Uladar», "Vesnyanka», "Kormoran», "Sonata», "Lazar'», «Dzvin», «Leleka») the distribution of starch grains is monomodal in size (one fraction is clearly distinguished), four types of native potato starch («Mag», "Albatros», "Kranich», «Grand») have a bimodal (two-fractional) size distribution of starch grains, in eight varieties of native potato starch («Divo», "Effect», "Favorite», "Vasilek», "Velikan», "Nakra», «Kolobok», «Meteor»), the distribution of starch grains is threemodal (three-fractional) in size, and in two varieties of native potato starch («Bryanskiy delikatesc» and «Krepysh»), the distribution of starch granules is fourmodal (four-fractional) [34].

\section{Amount of starch in potato tubers}

It should be noted that the average starch content in grains obtained from Eastern and Central European potato varieties is as follows: «Atlant»-18,5\%, «Lazurite» - 17,7\%, «Lasunok»- 18,5\%, «Lileya» - 14,1\%, «Mag»-19\%, «Skarb» - 14,5\%, «Suzor'ye»19,1\%, «Yavar» - 11,4\%, «Uladar» - 14,7\%, «Vesnyanka» - 18,3\%, «Albatros» - 17,2\%, «Kormoran» - 23\%, «Kranich» - 16,7\%, «Sonata $\rangle-16,9 \%$, «Lazar'» - 20,4\%, «Divo» 21,0\%, «Vestnik»-18,5\%, «Effect»-19,5\%, «Bryanskiy delikatesc»-16,6\%, «Favorite»14,5\%, «Grand» - 15,7\%, «Vasilek»-14,3\%, «Velikan»-17,4\%, «Nakra» - 20,1\%, «Kolobok»-13,2\%, «Krepysh»-11,1\%, «Meteor» - 13,5\%, «Dzvin» - 18\%, «Leleka»$18,5 \%[34,41]$. 

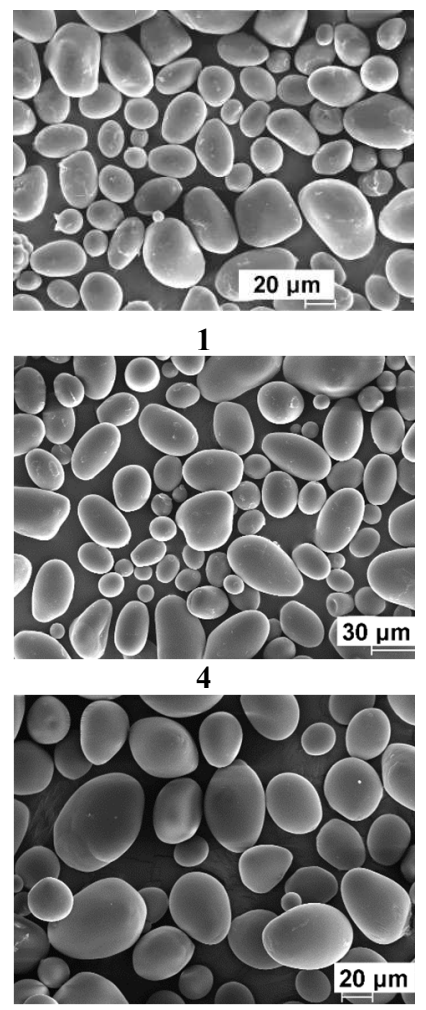

7

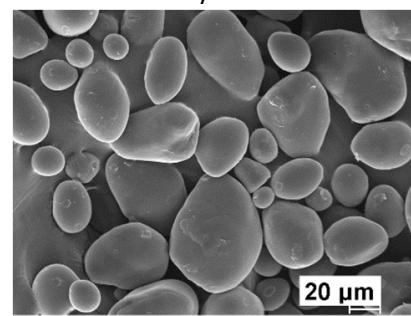

10

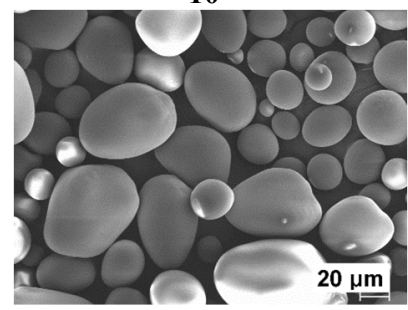

13

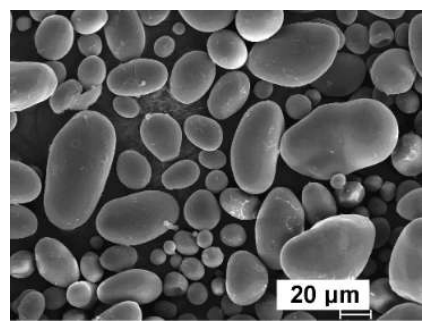

2

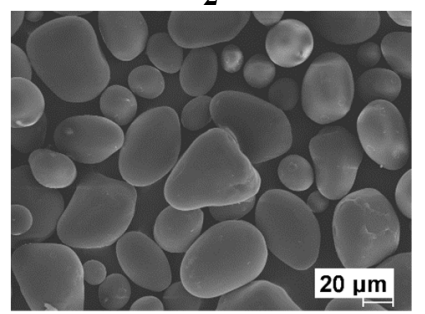

5

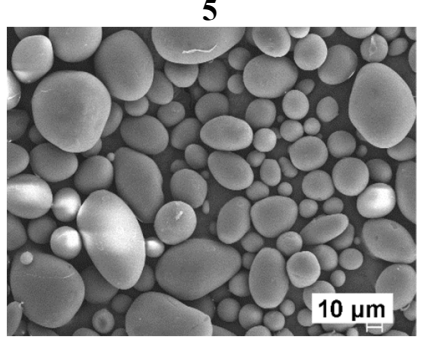

8
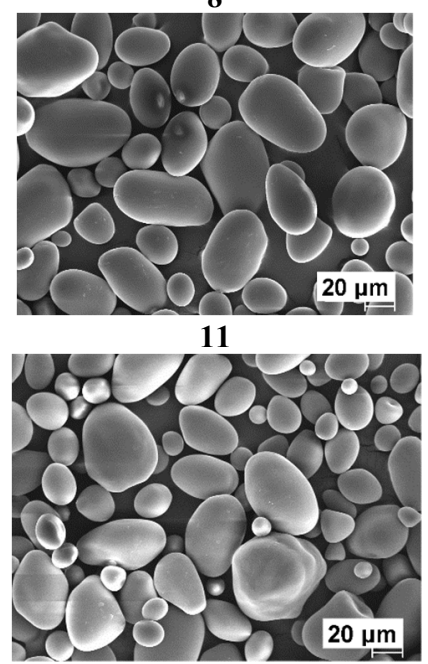

14

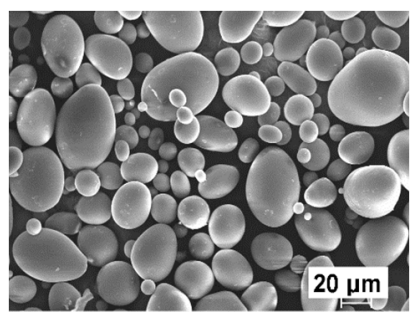

3

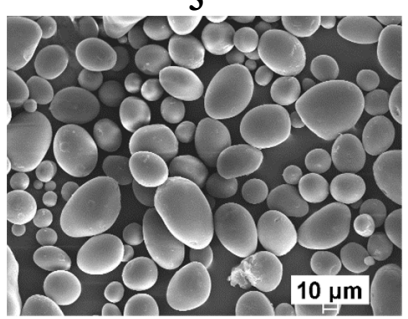

6

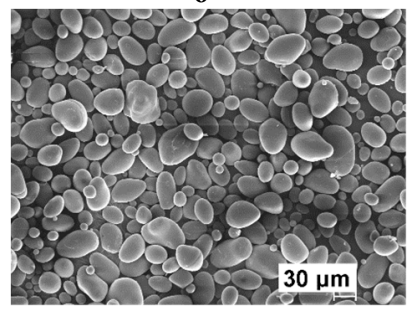

9

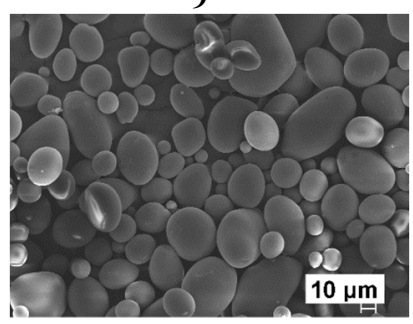

12

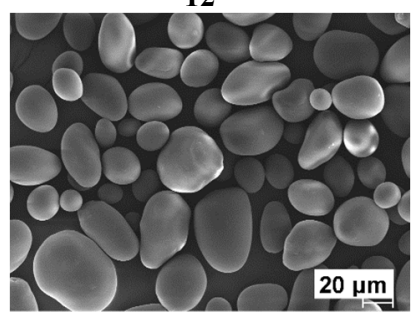

15

Figure 1. Scanning electron micrographs of native starch grains, isolated from Eastern and Central European potato varieties

1 - «Atlant», 2 - «Lazurit», 3 - «Lasunok», 4 - «Lileya», 5 - «Mag», 6 - «Skarb», 7 - «Suzor'ye», 8 - «Yavar», 9 - «Uladar», 10 - «Vesnyanka», 11 - «Albatros», 12 «Kormoran», 13 - «Kranich», 14 - «Sonata», 15 - «Lazar'» 

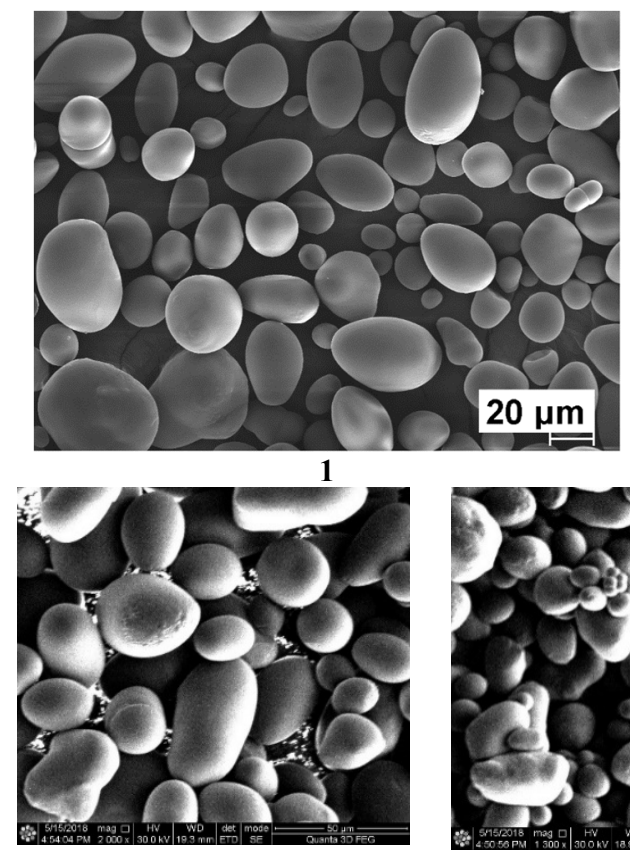

3

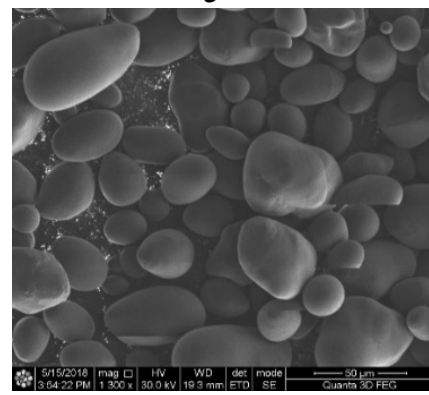

6

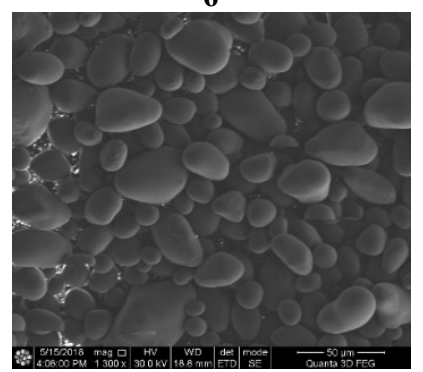

9

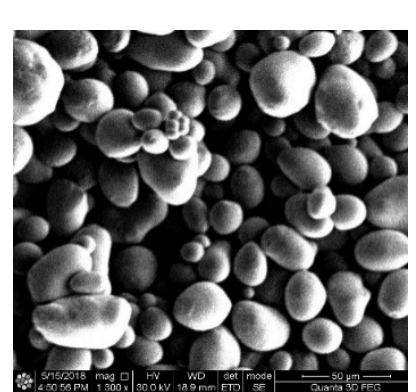

4

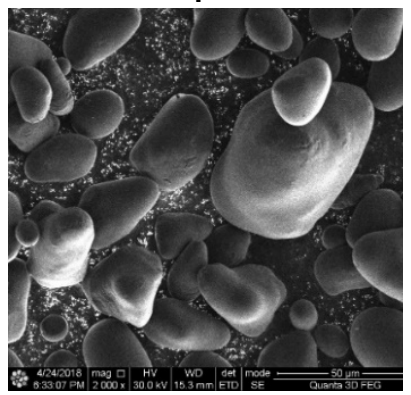

7

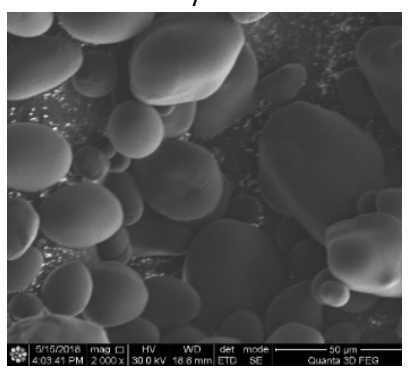

10

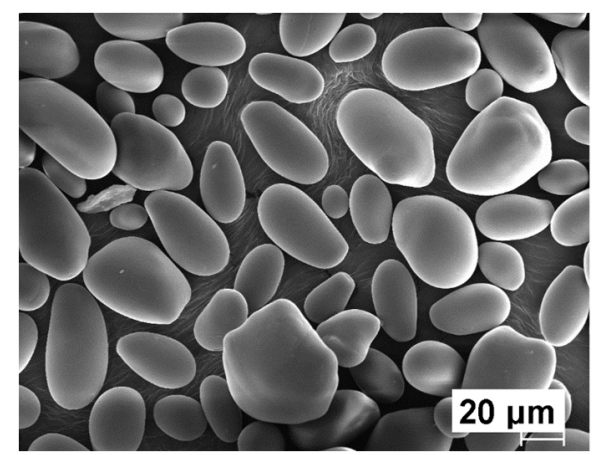

2

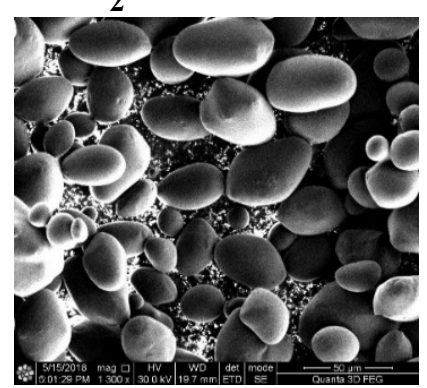

5

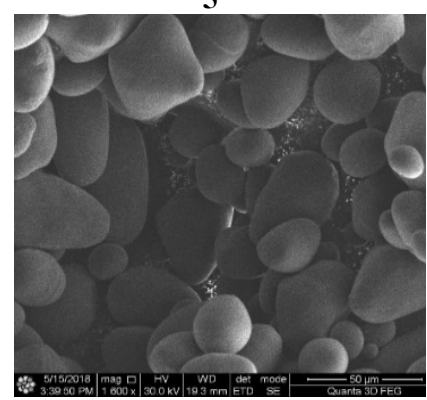

8

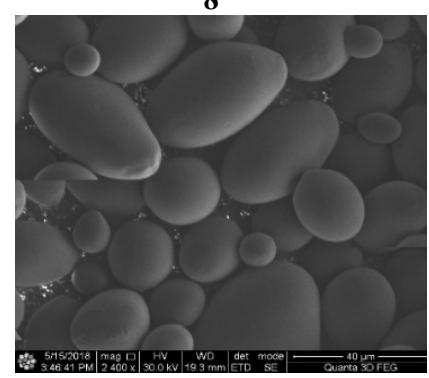

11

Figure 2. Scanning electron micrographs of native starch grains, isolated from Eastern and Central European potato varieties

1 - «Dzvin», 2 - «Leleka», 3 - «Bryanskiy delikatesc», 4 - «Favorit», 5 - «Grand»,

6 - «Vasilek», 7 - «Velikan», 8 - «Kolobok», 9 - «Krepysh», 10 - «Meteor», 11 - «Nakra» 

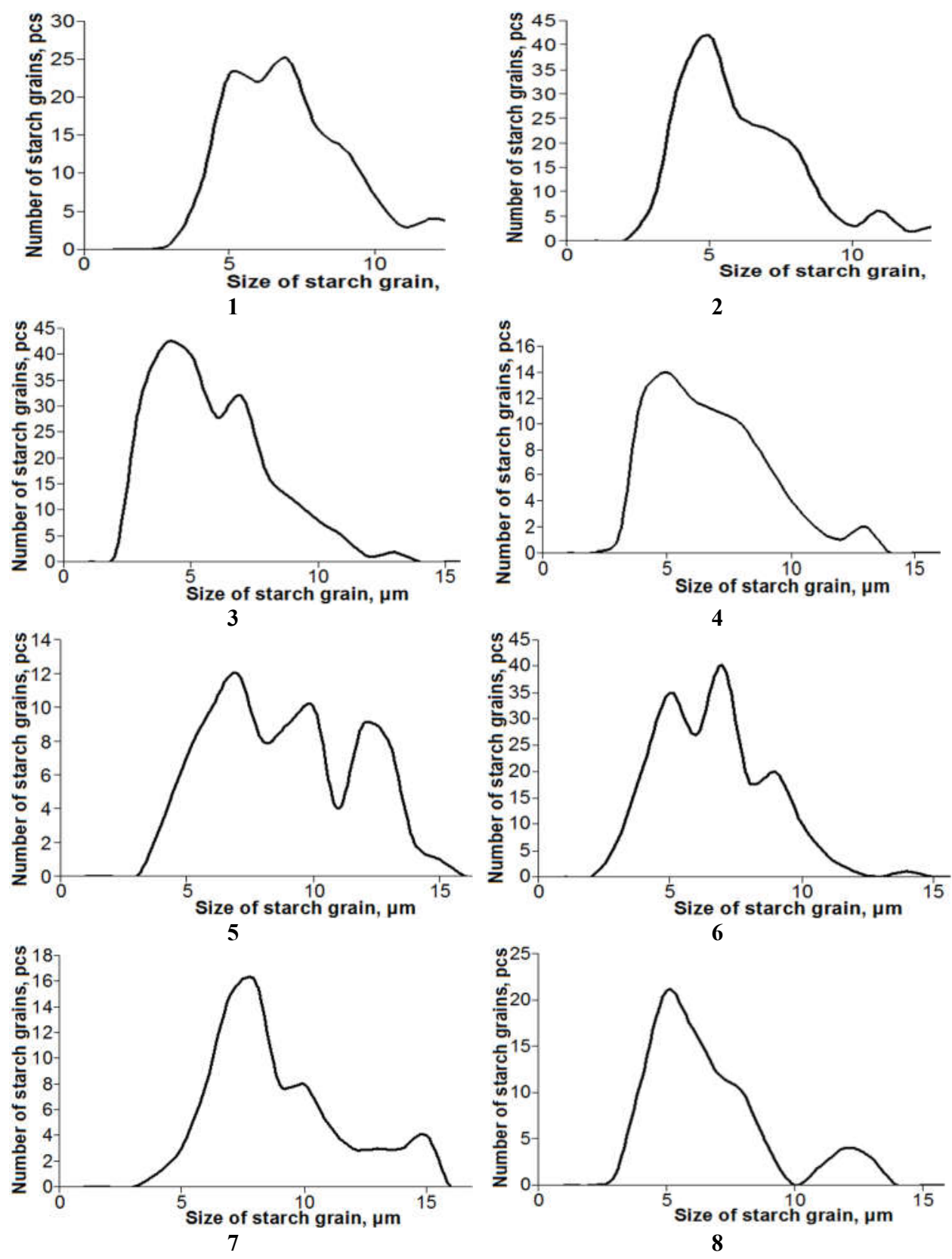

Figure 3. Granulometric analysis of grains of native starch, isolated from Eastern and Central European potato varieties:

1 - «Atlant», 2 - «Lazurit», 3 - «Lasunok», 4 - «Lileya», 5 - «Mag», 6 - «Skarb», 7 - «Suzor'ye», 8 - «Yavar» 

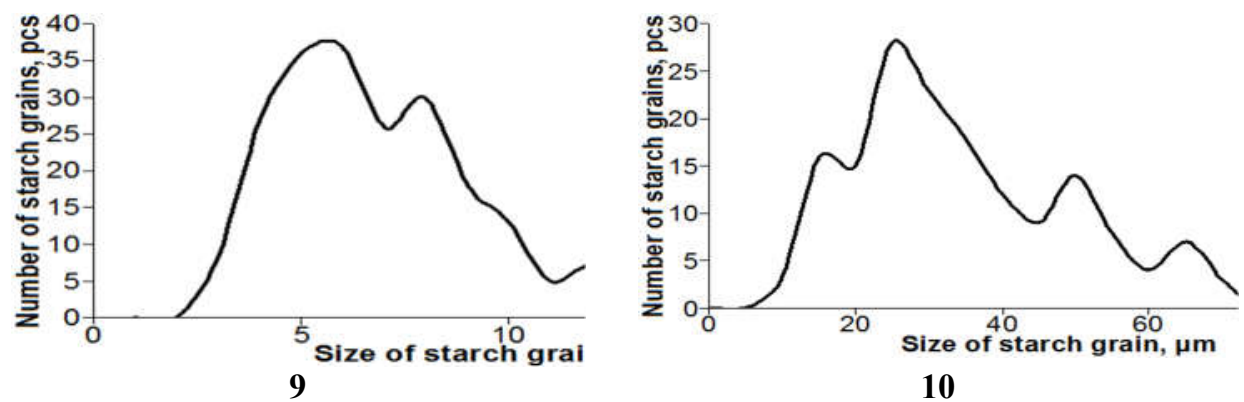

Figure 3 (Continuation). Granulometric analysis of grains of native starch, isolated from Eastern and Central European potato varieties:

$$
9 \text { - «Uladar», } 10 \text { - Vesnyanka» }
$$
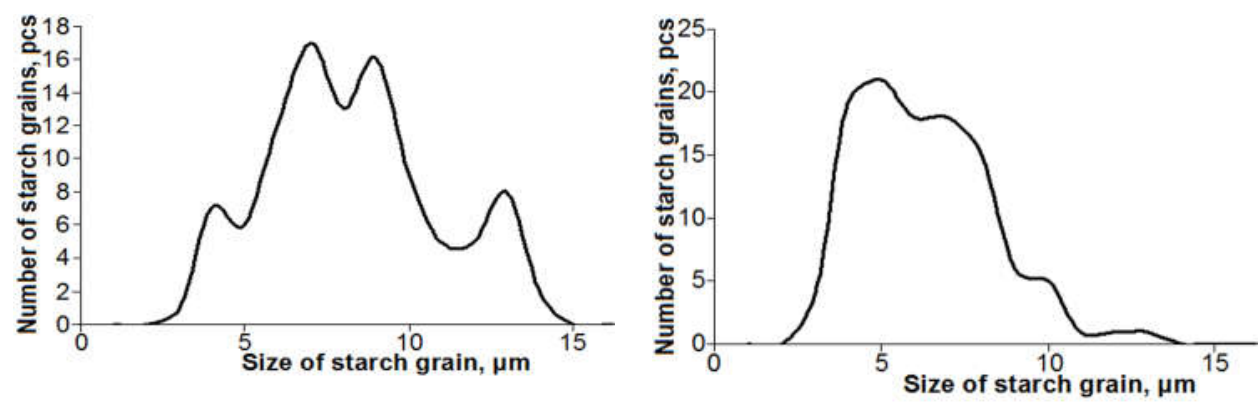

1

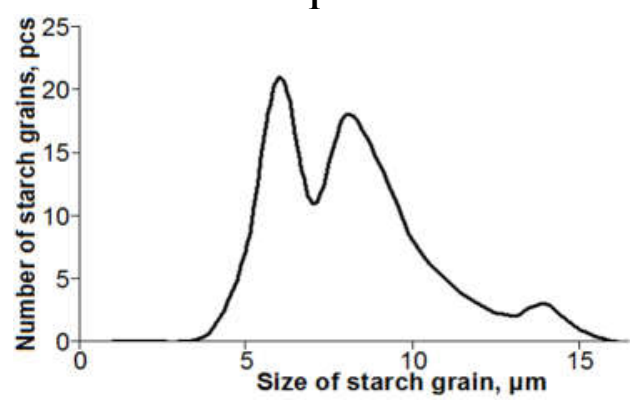

3

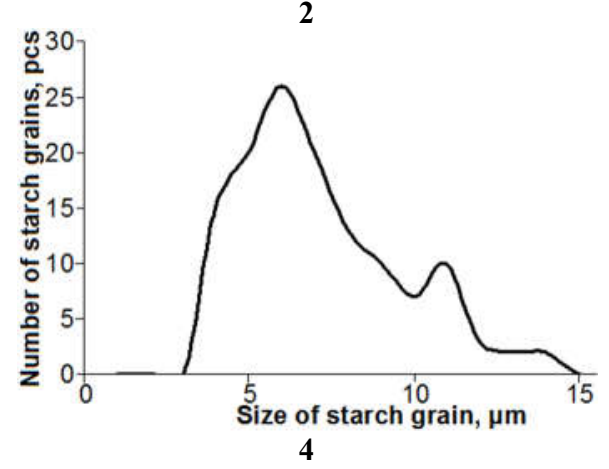

Figure 4. Granulometric analysis of grains of native starch, isolated from Eastern and Central European potato varieties:

1 - «Albatros», 2 - «Kormoran», 3 - «Kranich», 4 - «Sonata» 


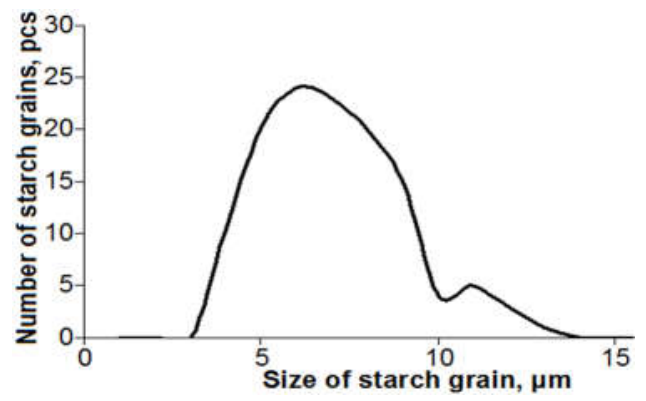

5

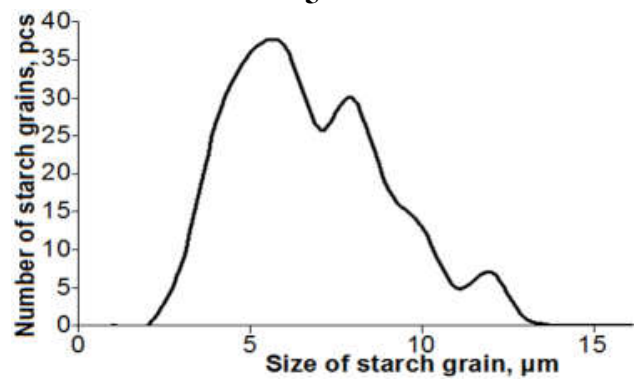

7

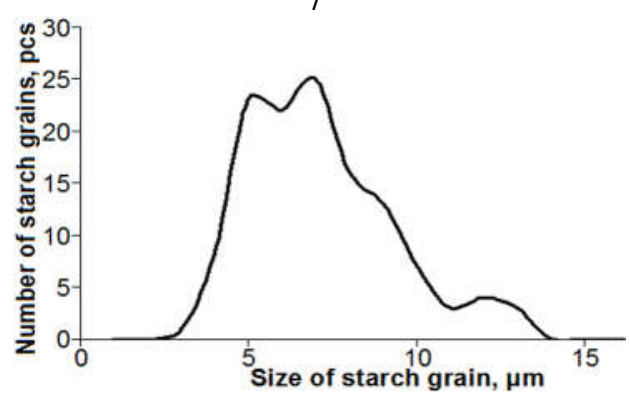

9

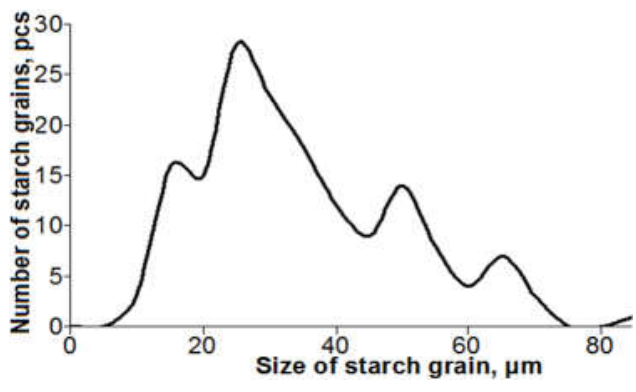

6

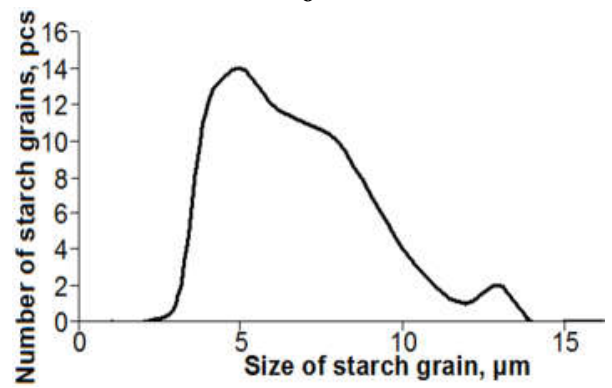

8

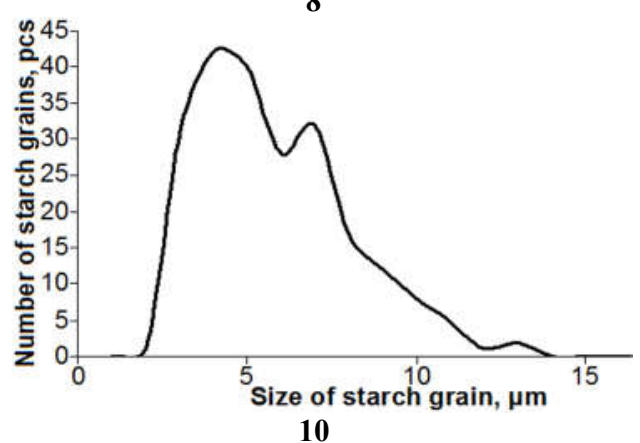

Figure 4 (Continuation). Granulometric analysis of grains of native starch, isolated from Eastern and Central European potato varieties:

5 - «Lazar'», 6 - «Bryanskiy delikatesc», 7 - «Favorit», 8 - «Grand», 9 - «Vasilek», 10 - «Velikan» 

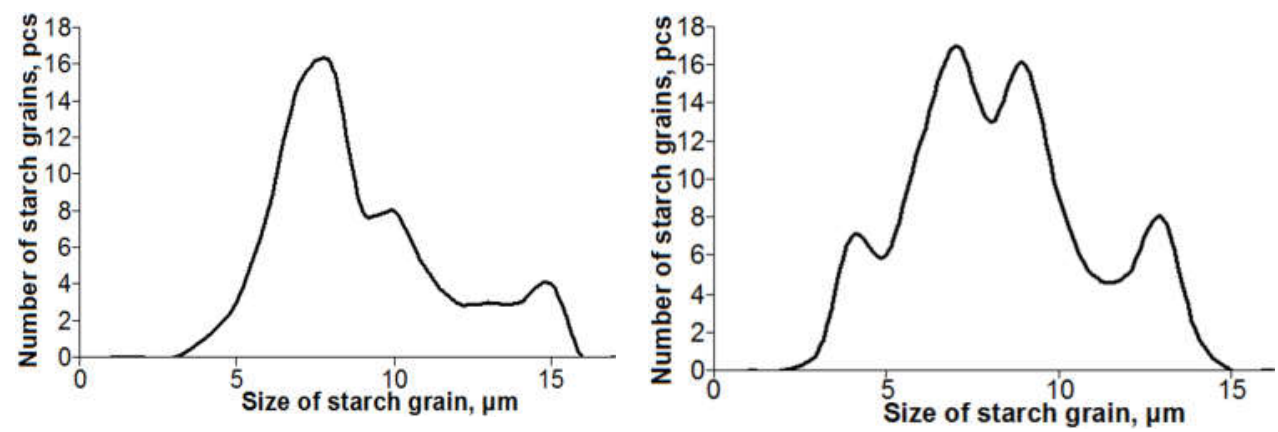

1
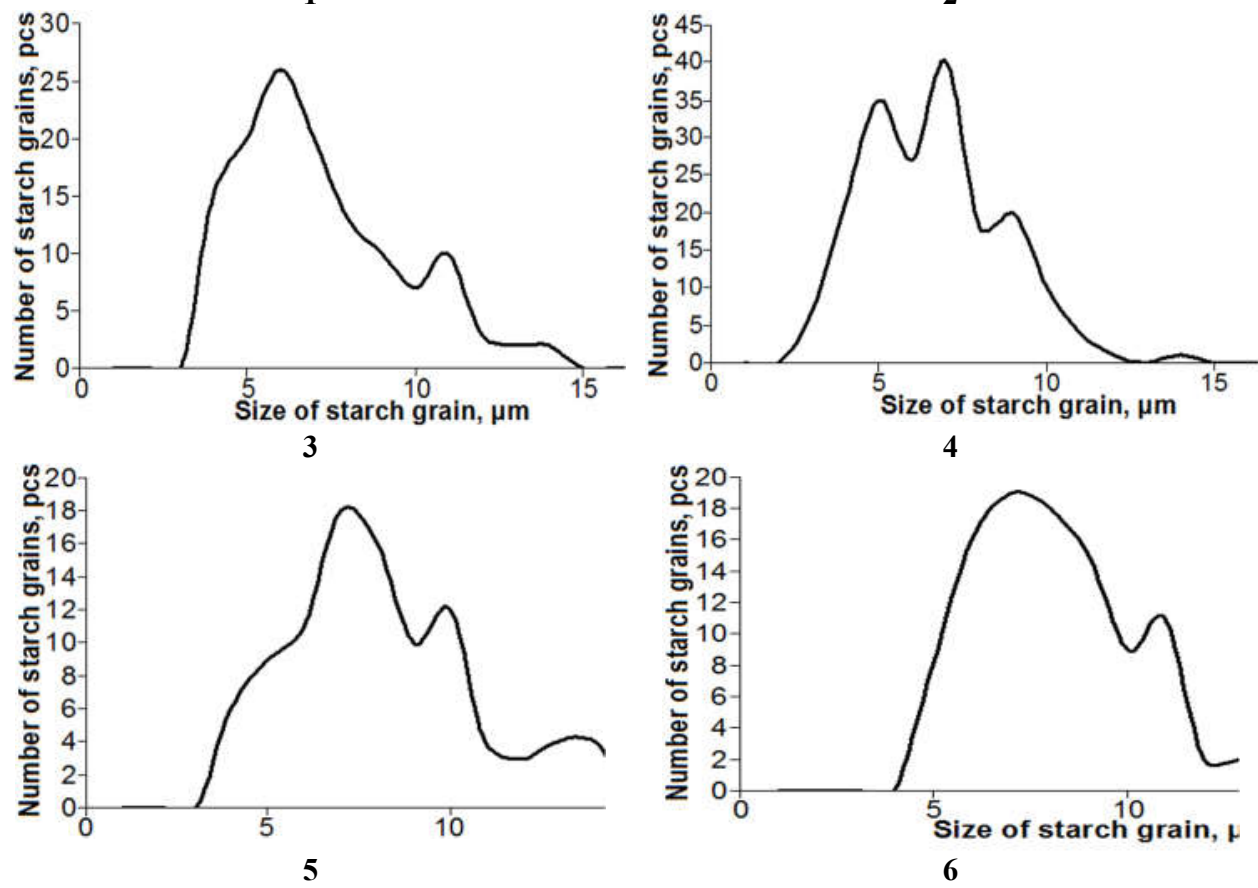

Figure 5. Granulometric analysis of grains of native starch, isolated from Eastern and Central European potato varieties

1 - «Kolobok», 2 - «Krepysh», 3 - «Meteor», 4 - «Nakra», 5 - «Dzvin», 6 - «Leleka»

\section{Discussion of the results}

Native starch is a natural polymer in which monomers (residues of $\alpha$-D-glucopyranose) are bound by $\alpha-(1 \rightarrow 4)$ - and $\alpha-(1 \rightarrow 6)$-glucoside bonds, forming amylose (linear polysaccharide) and amylopectin (branched polysaccharide buildings). Starch fractions (amylose and amylopectin) are compactly packed into starch grains (or granules) [1, 3, 32].

The source of starch-containing raw materials and the peculiarities of the structural organization of native starch largely determine the technological methods used for the fullest 
and most gentle extraction of the seeds of native starch from the plant cell [2,35]. To obtain native starch, it is required to prepare for processing vegetable starch-containing raw materials, destroy the plant cell, extract the native starch, wash it with clean water from associated impurities, dehydrate, dry, pack up and pack [2]. Thus, methods are known for processing potatoes for starch using a variety of technological schemes equipped with various types of processing equipment used for these purposes [34]. However, regardless of the hardware design, each of these methods includes the production stages that are common to all modern technologies for the production of potato starch: preparing potatoes for processing, grinding, extracting potato (cell) juice and pulp, cleaning starch, dehydrating it and drying $[1,8-10]$.

According to our results, as well as well-known data $[1-2,7-9]$, starch grains have an oval, spherical or irregular shape, their diameter varies between $0,001-0,2 \mathrm{~mm}$. Starch grains are divided into simple and complex: simple grains are homogeneous formations; complex a combination of smaller particles. The density of starch is on average $1,5 \mathrm{~kg} / \mathrm{m}^{3}$ [8].

Based on the analysis of the characteristics of the structure of native starch, it can be assumed that the main structural characteristic of the structure of native starch, determining its properties, is starch grain (granule) $[1,2,34,35]$. Thus, the peculiarities of the size and shape of starch grains determine (determine) the manifestation of the following properties (characteristics) of starch [8]:

1. The amount of bound moisture (the larger the starch granule, the more bound moisture is in the starch and vice versa).

2. The temperature of gelatinization (the larger the starch granule, the lower the temperature of its gelatinization and vice versa).

3. The ratio of the starch fractions of the branched fraction of amylopectin and linear amylose (the formation of starch granules is due to the interaction of the linear sections of amylopectin with each other or with amylose).

4. Rheological characteristics of starch paste (viscosity of starch paste is due to the ratio of amylopectin and amylose starch fractions).

The temperature of gelatinization, the amount of bound moisture, the viscosity of starch paste, the ratio of starch fractions, the color of the iodine sample and other physicochemical properties determine (determine) the size and shape of the starch grains [37].

\section{Conclusion}

The morphological structure of native starch granules depends on the potato variety and can vary widely. The small granules of potato starch of the «Lasunok» and «Skarb» varieties are only 5-7 microns in size, while the large starch granules of the varieties «Vasilek», "Nakra», "Kranich», "Vesnyanka» reach 80-90 microns. The shape of the granules themselves is also varied: correct and irregular oval, irregular many-sided, rounded (mainly characteristic of small granules).

The experimental data presented suggest that the size and morphology of starch granules is related to the starch content in grains of different varieties of native potato starch. With a larger average size of starch grains, the starch content decreases, and with a smaller average size, the percentage of starch content increases.

\section{References}

1. Gliuk N.G., Zhushman A.I., Ladur T.A., Shtyrkova E.A. (1985), Krakhmal i krakhmaloprodukty, Agropromizdat, Moscow. 
2. Andreev N.R. (2001), Osnovy proizvodstva nativnykh krakhmalov, Pishchepromizdat, Moscow.

3. Belitz H.-D., Grosch W., Schieberle P. (2009), Food Chemistry. $4^{\text {th }}$ revised and expanded edition, Springer-Verlag, Leipzig.

4. Makella M.J., Laakso S. (2006), Studies on Oat Starch with a Celloscope: Granule Size and Distribution, Starch/Starke, 36, pp. 159-163.

5. Sylvia de Pater, Martien Caspers, Marijke Kottenhagen, Henk Meima, Renaldo Ter Stege, Nick de Vetten (2006), Manipulation of starch granule size distribution in potato tubers by modulation of plastid division, Plant Biotechnology Journal, 4, pp. 123-134.

6. Jane J-L., Kasemsuwan T., Leas S., Zobel H., Robyt J.F. (1994), Anthology of starch granule morphology by scanning electron microscopy, Starch/Starke, 46, pp. 121-129.

7. J.BeMiller, R. Whistler (2009), Starch: chemistry and technology. $3^{\text {th }}$ edition, Academic Press. Burlington.

8. Pérez S., Bertoft E. (2010), The molecular structures of starch components and their contribution to the architecture of starch granules: a comprehensive review, Starch/Starke, 62, pp. 389-420.

9. Buleon A., Colonna P., Planchot V., Ball S. (1998), Starch granules: structure and biosynthesis, Int. J. Biol. Macromol., 23, pp. 85-112.

10. A.C. Eliasson (2004), Starch in food: structure, function and application, Woodhead Publishing ltd, Cambridge.

11. Yonemoto P.G., Calori D.M.A., Franco C.M.L. (2007), Effect of granule size on the structural and physico- chemical characteristics of wheat starch, Ciênc. Tecnol. Aliment., 27, pp. 761-771.

12. Takeda Y., Takeda C., Mizukami H., Hanashiro I. (1999), Structures of large, medium and small starch granules of barley grain, Carbohyd. Polym., 38, pp. 109-114.

13. Swinkels J.J.M. (1985), Composition and Properties of commercial Native Starches, Starch/Starke, 37, pp. 1-5.

14. Zobel H.F. (1988), Molecules to Granules: A Comperehensive Starch Review, Starch/Starke, 40, pp. 44-50.

15. Dengate H., Meredith P. (1984), Variation in size distribution of starch granules from wheat grain, J. Cereal. Sci., 2, pp. 83-90.

16. Stoddard F.L. (1999), Survey of starch particle-size distribution in wheat and related species, Cereal. Chem., 76, pp. 145-9.

17. Lindebloom N, Chang P.R., Tyler R.T. (2004), Analytical, Biochemical and Hysiochemical Aspects of Starch Granule Size, with Emphasis on Small Granule Starches: A Review, Starch/Starke, 56, pp. 89-99.

18. Uarrota V.G., Amante E.R., Demiate I.M., Vieira F., Delgadillo I., Maraschin M. (2013), Physicochemical, thermal, and pasting properties of flours and starches of eight Brazilian maize landraces (Zea mays L.), Food Hydrocolloid, 30, pp. 614-624.

19. Hebeish A., El-Rafie M.H., El-Sisi F., Abdel Hafiz F., Abdel-Rahman A.A. (1994), Oxidation of maize and rice starches using potassium permanganate with various reductants, Polym. Degrad. Stab., 43, pp. 363-372.

20. Halal S.L.M., Colussi R., Pinto V.Z., Bartz J., Radunz M., Carreño N.L.V., Dias, A.R.G., Zavareze E.R. (2015), Structure, morphology and functionality of acetylated and oxidised barley starches, Food Chem., 168, pp. 247-256.

21. Ribeiro L.S., Cordoba L.P., Colman T.A., Oliveira C.S., Andrade M.M.P., Schnitzler E. (2014), Influence of some sugars on the thermal, rheological and morphological properties of «pinhão» starch, J.Therm. Anal. Calorim., 117, pp. 935-942.

22. Malucelli L.C., Lacerda L.G., Carvalho Filho M.A.S., Fernández D.E.R., Demiate I.M., Oliveira C.S., Schnitzler, E. (2015), Porous waxy maize starch, J. Therm. Anal. Calorim., 120, pp. 525 532.

23. Colman T.A.D., Demiate I.M., Schnitzler E. (2014), The effect of microwave radiation on some thermal, rheological and structural properties of cassava starch, J. Therm. Anal. Calorim., 115, pp. 2245-2252.

24. Beninca C., Colman T.A.D., Lacerda L.G., Carvalho-Filho M.A.S., Demiate I.M., Schnitzler E. (2013), Thermal, rheological, and structural behaviors of natural and modified cassava starch granules, with hypochlorite solutions, J. Therm. Anal. Calorim., 111, pp. 2217-2222. 
25. Carmona-Garcia R., Sanchez-Rivera M.M., Mendez-Montealvo G., Garza-Montoya B., BelloPerez L.A. (2009), Effect of the cross-linked reagent type on some morphological, physicochemical and functional characteristics of banana starch (Musa paradisíaca), Carbohydr. Polym., 76, pp. 117-122.

26. Joshi M., Aldred P., McKinight S., Panozzo J.F., Kasapis S., Adhikari R., Adhukari, B. (2013), Physicochemical and functional characteristics of lentil starch, Carbohydr. Polym., 92, pp. 14841496.

27. Joint FAO/WHO Expert Committee on Food Additives (JECFA) (1992), Compendium of food additive specifications, vol. 1 and 2. FAO Food and Nutrition Paper 52/1, Food and Agriculture Organization of the United Nations, Rome.

28. Galliard T. (1987), Starch: properties and potential, J. Wiley \& Sons, Chichester.

29. Luallen T. Measuring starch in food (2004), Starch in Food Structure, Function and Applications, Polytechnic University of Valencia, Valensia, 1, pp. 185-207.

30. Passos M.L. (2010), Innovations in food engineering: new techniques and products, CRC Press, Boka Raton.

31. Copeland L., Blazek J., Salman H. et. al. (2009), Form and functionality of starch, Food Hydrocoll, 23, pp. 1527-1534.

32. Damodaran A.M., Parkin K.L., Fennema O.R. (2007), Fennema's Food Chemistry. $4^{\text {th }}$ edition, CRC Press, Boka Raton.

33. Information Internet: Potato starch. Technical conditions, Available at: http://files.stroyinf.ru/Data/327/32700.pdf

34. Litvyak V.V., Butrim S.M., Moskva V.V., Kozlova L.N., (2010), Morfologicheskaya kharakteristika krakhmal'nykh granul kartofelya (Solanum tuberosum) razlichnykh sortov, Vesci NAN Belarusi. Ser. biyal. navuk, 3, p. 99-103.

35. Litvyak, V.V., Yurkshtovich N.K., Butrim S.M., Moskva V.V., (2013), Atlas. Morfologiya krakhmala i krakhmaloproduktov, Minsk: Belaruskaya navuka, p. 217.

36. Litvyak V.V., Ospankulova G.H., Shaimerdenova D.A., Yurkshtovich N.K., Butrim S.M., Roslyakov Yu.F., (2016), Atlas: morfologiya polisakharidov, TOO «EDIGE», Astana, p. 335.

37. Litvyak V.V., Roslyakov Yu.F., Butrim S.M., Kozlova L.N., (2013), Krakhmal $i$ krakhmaloprodukty: monografiya, pod red. d-ra tehn. nauk, professora Yu.F. Roslyakova, FGBOUVPO «KubGTU», Krasnodar, p. 204.

38. Goldstein J., Yakovica H., (1978), Prakticheskaya rastrovaya elektronnaya mikroskopiya, M.: Mir, p. 656.

39. Goldstein J., Newbury D., Eclin P., Joy D., Fiori Ch., Lifshin F., (1984), Prakticheskaya rastrovaya elektronnaya mikroskopiya i rentgenovskiy analiz: $v 2-h$ knigah, Mir, Moskva.

40. Goldstein J., Newbury D., Eclin P., Joy D., Fiori Ch., Lifshin F., (1984), Rastrovaya elektronnaya mikroskopiya i rentgenovskiy microanaliz: $v$ 2-h knigah: Kniga 2., Per. s angl., Mir, Moskva

41. Litvyak Vladimir (2018), Size and morphological features of native starch granules of different botanical origin, Ukrainian Food Journal, 7(4), pp. 563-576.

42. Information Internet: Potatoes. Determination of starchiness and density of potatoes, Available at: http://www.spec-kniga.ru/tehnohimicheski-kontrol/tekhnohimicheskij-kontrol-brodilnyhproizvodstv/syre-brodilnyh-proizvodstv-kartofel.html 